6. Korostyilev V. S. Osnovyi funktsionalnogo obucheniya inoyazyichnoy leksike [Fundamentals of functional training in foreign vocabulary]. Voronezh : Izd-vo Voronezh. un-ta, 1990. 158 s. [in Russian].

7. Mykytenko N. O. Teoriia i tekhnolohii formuvannia inshomovnoi profesiinoi kompetentnosti maibutnikh fakhivtsiv pryrodnychykh spetsialnostei [Theory and technologies of formation of foreign professional competence of future specialists of natural specialties]. Doctor's thesis. Ternopil, 2011. 450 s. [in Ukrainian].

8. Gnatkevich Yu. V. Metodicheskaya tipologiya passivnoy leksiki (na materiale nemetskogo yazyika) [Methodological typology of passive vocabulary (based on material of German language)]. Candidate's thesis. KGPIYa. Kyiv, 1971.239 s. [in Russian].

9. Smolina S. V. Metodyka formuvannia inshomovnoi leksychnoi kompetentsii [Methods of formation of foreign language lexical competence]. Inozemni movy. 2010. № 4. S. 16-23. [in Ukrainian].

\title{
Polianychko O. D. Structure of the cognitive component of lexical competence of future history teachers
}

The article defines the structure of the cognitive component of lexical competence of future history teachers. It is proved that the cognitive component as the main component of lexical competence is based on cognitive psychology, on the principle of consciousness in teaching and on the theory of socio-constructivism, in which the student is an active participant in the learning process. Structural elements of the cognitive component are disclosed, such as thinking, perception, attention, memory and imagination.

Thinking is responsible for the active comprehension and processing of lexical material, its transformation and preservation in the internal vocabulary of students. This psychological process plays an important role, because vocabulary is crucial for developing the ability to think in a foreign language.

Perception as a psychological process, which consists in the reflection of human objects and phenomena, in the aggregate of all their qualities in the direct effect on the senses, is responsible for creating a free and complete image of a foreign language. The task of perception is to economically use thought processes. Perception identifies, selects, classifies, and encodes in a way the necessary and important information.

Attention plays a significant role in the formation of the lexical competence of future history teachers. Attention makes the image of the word clear and complete, so it is a prerequisite and a component of successful foreign language learning. When mastering a foreign language vocabulary, it ensures the correct perception of lexical units, the peculiarities of their pronunciation and use.

Human memory allows you to store the entire volume of learned foreign language lexical material and allows it to be used in the process of foreign language communication.

In the process of forming the lexical competence of future history teachers, an important function is played by a cognitive component, such as imagination. Which, in turn, is closely related to images.

The active work of students' cognitive processes in mastering a foreign language vocabulary provides a conscious and effective assimilation of the material and becomes a successful prerequisite for the formation of a system of stable, flexible lexical knowledge and skills.

Key words: competence approach, cognitive component, lexical competence, thinking, perception, attention, memory, imagination.

УДК 37: 5 «199/2010»

DOI https://doi.org/10.31392/NPU-nc.series5.2020.72-2.29

Приступа Я. В.

\section{ІСТОРІОГРАФІЯ ШКІЛЬНОЇ ПРИРОДНИЧОЇ ОСВІТИ В УКРАЇНІ НАПРИКІНЦІ ХХ - НА ПОЧАТКУ ХХІ СТОЛІТТЯ}

Оновлення парадигми природничої освіти на усіх ї̈ етапах обумовлене необхідністю ї̈ кореляції з сучасним рівнем розвитку природничих наук, вимогами до сучасної освіченої людини, реаліями сучасного світу і культури є об'єктивною вимогою часу. Важслиим є те, що саме природнича освіта сприяє створенню цілісного уявлення про наукову картину світу, усвідомленню людиною свого місия у світі, як невід 'ємної частини природи, соџіальної адаптаиії молоді до життя у швидкоплинних умовах соиіально-економічного розвитку краӥни. Тому актуальною стає проблема розвитку шкільної природничої освіти в Україні, але не зважаючи на досить значну кількість доробок, розвідок, досліджень, які безпосередньо чи опосередковано торкаються неї, поки що недостатньо досліджень, які б висвітлювали історіографію розвитку шкільної природничої освіти в Україні кіния XX- початку XXI cm. У статті розглянуто проблему розвитку шкільної природничої освіти в Украӥні наприкінці XX-початку XXI ст. крізь призму історіографічного дискурсу, щзо є важливим під час аналізу розвитку історико-педагогічної науки як иілісної системи знань у співвідношенні різних напрямів єдиного предметного поля історії педагогіки. На основі проаналізованих джерел виокремлено три етапи становлення природничої освіти: радянський, етап перебудови освіти та сучасний етап. Кожен період має свої особливості у висвітленні проблеми, зумовлені конкретно історичними, ідеологічними, сочіокультурними, політичними чинниками, а також розвитком освіти та історико-педагогічної думки в Україні. Перед сучасними істориками шкільної природничої освіти стоїть щее чимало проблем, які очікують свого вирімення, вимагають серйозної і поглибленої розробки.

Зростання ціннісного потенціалу шкільної біологічної освіти в ХХІ сm. зумовлює необхідність відбору і структурування наукових положень біологічної науки з дотриманням аксіологічного принщипу.

Ключові слова: історіографія, зміни, етапи, педагогічна наука, природнича освіта, природознавство, розвиток, хронологічна послідовність. 
Розбудова вітчизняної освітньої системи в умовах кардинальних змін, вимагає розв'язання нагальних проблем, які стримують іiі якісний розвиток. 3-поміж завдань, які потребують нині першочергового розв’ язання, одне з чільних місць посідає потреба в реформуванні шкільної природничої освіти. При поглибленому вивченню дослідником будь-якої проблематики першорядне значення має вивчення попереднього досвіду, систематизація і осмислення того, що зроблено його попередниками, накопичено наукою в обраній ним галузі знання. Історико-педагогічне знання становить основу сучасної й майбутньої педагогічної культури. Низка питань шкільної природничої освіти, які очікують грунтовного свого вирішення, вимагають серйозної і поглибленої розробки. Одним з таких питань осмислення шляху, пройденого шкільною природничою освітою, узагальнення досвіду вирішення тих чи інших проблем в історіографічному дискурсі, виявлення ступеню та рівня їх розробки.

Актуальною стає проблема розвитку шкільної природничої освіти в Україні, але не зважаючи на досить значну кількість доробок, розвідок, досліджень, які безпосередньо чи опосередковано торкаються неї, поки що недостатньо досліджень, які б висвітлювали історіографію розвитку шкільної природничої освіти в Україні кінця XX - початку XXI ст.

Mema cmammi полягає у здійсненні історіографії розвитку шкільної природничої освіти в Україні наприкінці XX - початку XXI століття.

В історіографії розвитку шкільної природничої освіти ми можемо чітко виділити три етапи: 1) радянський (1920-ті - 1980-ті роки); 2) етап перебудови освіти (1980- ті - 1990-ті); 3) сучасний (1990-ті - 2010-ті роки). Кожен період має свої особливості у висвітленні проблеми, зумовлені конкретно історичними, ідеологічними, соціокультурними, політичними чинниками, а також розвитком освіти та історико-педагогічної думки в Україні.

В історіографії радянського періоду (1920-ті - 1980-ті рр.) важливу роль відіграють праці радянських істориків освіти і педагогіки - С. Єгорова, М. Константинова, М. Кузьміна, Є. Мединського, В. Струмінського, Б. Райкова [10], Н. Фігуровського та В. Зубова; монографії В. Смірнова, В. Федоровой [11], І. Шульги [10] та інших. Так, І. Шульга в «Нарисах з історії шкільного природознавства в Росії» (1955) в хронологічній послідовності, починаючи з першої половини XVIII і закінчуючи 1917 р., послідовно висвітлив історію шкільного природознавства в Росії. У вступі автор зазначав, що «Ознайомлення молоді - студентів педінститутів і навіть досвідчених учителів з історією шкільного природознавства в Росії сприятиме дальшому поліпшенню викладання біології в школі та вихованню почуття радянського патріотизму і національної гордості за прогресивні традиції нашої вітчизняної школи» [10, с. 6]. Спираючись на погляди найбільш прогресивних вітчизняних педагогів, І. Шульга проаналізував соціальні, економічні, культурні, політичні чинники і фактори, які впливали на розвиток шкільного природознавства. Розвитку методики природознавства в дореволюційній Росії присвячена монографія В. Федорової (1958) [11]. Робота складається 3 трьох частин: перша частина аналіз передумов виникнення методики природознавства, стан шкільного природознавства в першій половині XIX століття; друга частина монографії - становлення методики природознавства як науки у другій половині XIX століття; третя частина роботи - особливості викладання природознавства на початку ХХ століття.

Добірка статей відомого російського педагога-природника Б. Райкова «Пути и методы натуралистического просвещения» (1960) за різні роки з історії шкільного природознавства та з методики його викладання займає важливе місце в становленні природничої освіти [10].

Окремі аспекти проблеми змісту природничих дисциплін у середніх навчальних закладах Росії другої половини XIX століття висвітлені у науковій праці «Очерки по истории средней школы в России второй половины XIX века» (1950) Ш. Ганеліна [3]. У 1976 році з'являється праця за редакцією О. Піскунова «Очерки истории школы и педагогической мысли народов СССР. Вторая половина XIX века», яка стала фундаментальною у становленні природничої освіти. У збірці проаналізовано суспільно-педагогічний рух i реформу народної освіти, пояснюються принципи урядової політики в галузі середньої освіти та педагогічної думки народів СРСР у другій половині XIX ст. Персоналії окремих вчених-природознавців, їхня науково-педагогічна та творча спадщина стали предметом дослідження Б. Райкова (В. Зуєв), С. Соболя (Ч. Дарвін), В. Гурвича (І. Сєчєнов), О. Некрасова (Ч. Дарвін, К. Тімірязєв), К. Ягодовського (Д. Кайгородов, О. Герд) та інших.

Вагомий внесок в закладення фундаменту природничих дисциплін зробили наукові публікації В. Смірнова та Л. Смірнової, які присвячені проблемі педагогічної освіти і створенню навчальної літератури; статті В. Пономарьової, Л. Хорошилової, що розкривають особливості освітньої політики Катерини II. Цінні відомості з історії викладання природознавства в російській школі знаходимо в статті О. Шибанова «Из истории преподавания естествознания в русской школе» (1936), де зосереджено увагу на особливостях викладання природознавства в школі в період з 1804 по 1877 роки, зокрема на світоглядній позиції О. Герди.

Етап перебудови освіти (1980-ті - 1990-ті), підгрунтям якого стала союзна реформа загальноосвітньої і професійної школи (1984) як дійова перебудова освіти під впливом громадського та педагогічного руху на основі принципів розвитку шкільної освіти: демократизація, деуніфікація, деідеологізація, націоналізація. Міністерство народної освіти УРСР розпочало перебудову шкільної освіти у контексті Закону про мови в УРСР (1989), Декларації про державний суверенітет (1990) 3 метою створення національної 
системи шкільної освіти за такими напрямами: розробка національного освітнього законодавства; відродження української школи, відновлення національного компонента у змісті освіти. Прискорена корекція шкільної реформи почалася у 1984 році, завданням якої було комп’ютеризація навчання. Впровадження 11-річного терміну навчання, часткового перегляду навчальних програм і підвищення зарплати вчителям реальні наслідки, до яких призвела реформа.

Нова фаза розвитку школи розпочалася 1988 році, а саме всебічна демократизація і гуманізація освіти та відмова від тотальної уніфікації і професіоналізації загальноосвітньої школи. Квінтесенція нової реформи - заміщення статичної моделі освіти на новітню динамічну: запровадження обов'язкового освітнього мінімуму обсягом дев'ять років, закінчення 11 класів було необов'язковим, адже держава не виступала гарантом його доступності, результатом цього повинно було стати підвищення якості освіти, позбавлення шкіл та училищ від «зайвих» учнів.

Запроваджена реформа призвела до трансформації радянської школи: низький рівень регламентації шкільного життя, поява ліцеїв, гімназій, новітні методи викладання дисциплін гуманітарного циклу. Перехід до новочасної стратегії функціонування культури (адаптація до ринкових відносин) спричинило глобальну комерціалізацію культури, повну залежність від рекламодавців. Певний державний контроль попри все зберігся: обов'язкові державні освітні стандарти, єдина форма атестата, диплома.

Останніми роками підвищився інтерес до вивчення змісту природничої освіти в Україні (1990-ті 2010-ті роки). У теоретичному осмисленні обраної теми відіграли фундаментальні дослідження в галузі історії українського шкільництва та шкільної освіти М. Бурди, В. Добровольського, О. Пометун, О. Сухомлинської та ін. Тенденції щодо розширення суті історико-педагогічних надбань минулого знаходимо в працях С. Гончаренка, М. Свтуха, І. Зязюна, О. Савченко, М. Сметанського, М. Ярмаченка.

Науковий інтерес викликає монографія Л. Березівської «Реформування шкільної освіти в Україні у XX столітті», де розглянуто проблема розвитку і становлення середньої освіти в Україні у XX столітті. Перший розділ роботи присвячений спробам реформування шкільної освіти в імперську добу (1899 - 1917 рр.), де розкрито проекти зміни в середній освіті цього періоду, проаналізовано державно-громадські ініціативи в існуванні школи, зокрема реальних училищ, висвітлено діяльність міністра П. Ігнатьєва в галузі освіти. Проведено дослідження розвитку шкільної освіти у різних регіонах України: на Волині (С. Бричок, М. Горний, Т. Джаман, Л. Сршова, В. Рожко, Ю. Толочний), Київщині (С. Бабишин, Л. Березівська, І. Довгань, Г. Кільова, І. Мороз, М. Скиба, О. Школа), Поділлі (О. Комарницький, А. Лисий, В. Прокопчук). Особливості становлення і розвитку шкільної природничої освіти в Україні можна прослідкувати завдяки працям сучасних істориків науки, таких як О. Коновець, В. Онопрієнко, Ю. Павленко, С. Руда, С. Хорошева, Ю. Храмов. У монографії «Природознавство в Україні до початку ХХ ст.» (2001) крізь призму історико-культурного та освітнього спектрів представлена передісторія і еволюція природознавства в Україні до початку XX ст., зокрема математики, механіки, фізики, хімії, біології та інших наук [9].

Особливості розвитку природничої освіти, освітніх процесів України кінця XX - початку XXI століття частково розглядалися в працях учених-педагогів сучасності: О. Біди, В. Буринського, О. Савченко, Т. Васютіної. Також у працях висвітлено погляди педагогів даного періоду на зміст викладання природознавства у вітчизняній школі [1]. Т. Васютіна присвятила статтю «Історія становлення курсу «Природознавство» в українській школі» аналізу змісту курсу «Природознавство» та етапам його становлення в українській школі.

Поповнення історіографічного знання знаходимо у сучасних дисертаційних дослідженнях. Так, праця I. Лисенко «Розвиток освіти та педагогічної думки на Чернігівщині кінця XIX - початку XX століття» (2005), розкриває окремі питання розвитку середньої освіти на Чернігівщині зазначеного періоду; О. Шевчука «Організація і зміст навчально-виховного процесу Колегії Павла Галагана: традиції і новаторство (1870 - 1920 рр.)» (2004), в якому розглядаються деякі аспекти викладання природничих дисциплін у цьому навчальному закладі; А. Синявської «Становлення та розвиток комерційної освіти в Західній Україні (XIX століття)» (2004), в дисертаційному дослідженні проаналізовано діяльність окремих комерційних середніх навчальних закладів Західної України; 3. Саф’янюк «Розвиток теорії та практики реальної освіти на західноукраїнських землях (1849-1939 рр.)» (2007) та ін. Н. Васильєва вивчала становлення природничонаукової освіти в Росії XVIII - першої половини XIX століття (до реформ 60-х років) (2008).

В дисертації А. Мартін (2008) здійснено аналіз розвитку змісту природничої освіти у вітчизняній середній школі (друга половина XIX - початок XX ст.): досліджено вплив досягнень природничої науки на зміст шкільного курсу природничих дисциплін в зазначений період, визначено основні шляхи реформування змісту природничої освіти, виявлено проблеми викладання природничих дисциплін в середній школі зазначеного періоду та шляхи їх вирішення [6].

Генезу природничої освіти проілюстровано у дисертації Т. Собченко (2007). Також авторкою узагальнено науково-педагогічні погляди і внесок провідних учених другої половини XIX - початку XX століття у природничу освіту молодших учнів; обгрунтовано етапи розвитку природничої освіти в Україні досліджуваного періоду (1852-1870 рр. - етап відновлення природознавства в початкових класах, інтенсивного розвитку теоретичних засад природничої освіти, шляхів їі реалізації у практиці; 1871-1900 pр. - етап вилучення природознавства з початкової школи, активної діяльності представників громадсько-педагогічного руху за його відновлення; науково-методичного обгрунтування здійснення природничої освіти; 1901-1920 рр. - етап поновлення 
початкової природничої освіти, критики стану шкільного природознавства вченими, педагогами, їх боротьби за підвищення рівня природничої освіти учнів). Досліджено досвід (науково-методичне підгрунтя, форми, методи, засоби) здійснення природничої освіти в початковій школі другої половини XIX - початку XX століття. I. Шоробура присвятила свою докторську дисертацію (2007) становленню і розвитку шкільної географічної освіти в Україні (XIX-XX століття). Раціональне зерно дослідження - системний аналіз теорії та практики розвитку шкільної географічної освіти в Україні, визначено і науково обгрунтовано етапи і тенденції іiї розвитку на основі детермінованого аналізу конкретно-історичних умов, схарактеризовано особливості становлення географічної освіти. Становленню та розвитку шкільної географічної освіти в Україні у першій половині ХХ століття присвячена дисертація Л. Мельничук (2004). О. Корнєєв в дисертаційній роботі «Розвиток географічного краєзнавства в школах України (1910-1970)» (2004) дослідив основні напрями розвитку географічного краєзнавства названого періоду, визначивши особливості в різні історичні періоди на території країни.

Дослідження на тему «Розвиток теорії і практики організації лабораторних робіт з фізики в середніх школах України (кінець XIX - початок XX століття)» (2005) І. Студенкова розкриває еволюційний процес та практику організації лабораторних робіт з фізики в середніх школах України - досліджено педагогічні основи навчально-виховного процесу в тогочасних середніх навчальних закладах. [1].

Неоціненим є значення у розвитку шкільної природничої освіти природничо-наукові з'їзди. В роботі М. Караванської (2006) на основі документальних матеріалів загальноросійських природничо-наукових з'їздів другої половини ХІХ століття вперше проаналізовані передумови, перші спроби, діяльність, еволюція та наслідки природодослідницьких з’їздів в історії української науки. [5].

\section{Використана література:}

1. Гуцал Л. Розвиток шкільної природничої освіти на Правобережній Україні (друга половина XIX - початок XX століття : автореф. дис. ... канд. пед. наук : 13.00.01. Житомир, 2011. 22 с.

2. Зародження природознавчої освіти та методики природознавства і сільськогосподарської праці / О. Біда та ін. Вісник Черкаського університету. 2010. № 189, ч. 1. С. 8-13.

3. Очерки по истории средней школы в России второй половины XIX века. Москва : Учпедгиз, 1950. 304 с.

4. Українська історіографія історії педагогіки / Н. М. Гупан. Київ : «А. П. Н.», 2002. 224 с.

5. Караванська М. Природничо-наукові з'їзди в історії української науки (друга половина XIX - початок XX ст.) : автореф. дис. ... канд. іст. наук : 07.00.07. Київ, 2006. 19 с.

6. Мартін А. М. Розвиток змісту природничої освіти у вітчизняній середній школі (друга половина XIX - початок ХХ століття) : автореф. дис. ... канд. пед. наук : 13.00.01. Кіровоград, 2008. 20 с.

7. Нариси з історії шкільного природознавства в Росії. Київ : Рад. школа. 1955. 290 с.

8. Никитюк Л. В. Становлення та розвиток природничої освіти в гімназіях України (друга половина XIX початок ХХ століття) : дис. ... канд. пед. наук : 13.00.01. Харків, 2012. 206 с.

9. Природознавство в Україні до початку ХХ ст. в історичному, культурному та освітньому аспектах / Ю. В. Павленко, С. П. Руда, С. А. Хорошева, Ю. О. Храмов. Київ : Видавничий дім «Академперіодика», 2001. 420 с.

10. Пути и методы натуралистического просвещения / Б. Е. Райков. Москва : Госпедиздат, 1960. 484 с.

11. Развитие методики естествознания в дореволюционной России / В. Н. Федорова. Москва : Учпедгиз, 1958. 434 с.

\section{References:}

1. Bida O. Zarodzhennia pryrodoznavchoi osvity ta metodyky pryrodoznavstva i silskohospodarskoi pratsi [The origin of science education and methods of natural science and agricultural labor] Visnyk of Cherkasy university, 189 (1), 2010. 8-13. [in Ukrainian]

2. Halenin Sh. Ocherki po istorii sredney shkolyi v Rossii vtoroy polovinyi XIX veka [Essays on the history of secondary school in Russia in the second half of the 19th century] Moscow : Edpedgym, 1950. 304 p. [in Russian]

3. Hupan N. Ukrainska istoriohrafiia istorii pedahohiky. [Ukrainian historiography of the history of pedagogy] Kyiv : «A.P.N.», 2002, 224 p. [in Ukrainian]

4. Hutsal L. Rozvytok shkilnoi pryrodnychoi osvity na Pravoberezhnii Ukraini (druha polovyna XIX - pochatok XX stolittia) [The development of school science education in Right-Bank Ukraine (second half of XIX - beginning of XX century)]: extended abstract of candidate's of ped. sciences: 13.00.01, Zhytomyr, 2011. 22 p. [in Ukrainian]

5. Karavanska M. Pryrodnycho-naukovi zizdy v istorii ukrainskoi nauky (druha polovyna XIX - pochatok XX st.) [Natural science congresses in the history of Ukrainian science (second half of XIX - beginning of XX century)]: extended abstract of candidate's thesis of hist. sciences: 07.00.07. Kyiv, 2006. 19 p. [in Ukrainian]

6. Martin A. Rozvytok zmistu pryrodnychoi osvity u vitchyznianii serednii shkoli (druha polovyna XIX - pochatok XX stolittia): [The development of the content of natural education in the national secondary school (second half of XIX - beginning of XX century]: extended abstract of candidate's thesis of ped. sciences: 13.00.01. Kirovograd. 20 p. [in Ukrainian]

7. Nykytiuk L. Stanovlennia ta rozvytok pryrodnychoi osvity v himnaziiakh Ukrainy (druha polovyna XIX pochatok XX stolittia) [Formation and development of natural education in high schools ofUkraine (second half of XIX beginning of XX century)]: thesis of ped. sciences candidate: 13.00.01 Kharkiv, 2012. 206 p. [in Ukrainian]

8. Pavlenko Ju. Pryrodoznavstvo v Ukraini do pochatku KhKh st. v istorychnomu, kulturnomu ta osvitnomu aspektakh [Natural science in Ukraine until the beginning of the twentieth century in historical, cultural and educational aspects], Kyiv : publishing house «Akademperiodyka», 2001. 420 p. [in Ukrainian]

9. Raykov B. Puti i metodyi naturalisticheskogo prosvescheniya [Ways and methods of naturalistic enlightenment]. Moscow : Gospedizdat, 1960. 484 p. [in Russian]

10. Fedorova V. Razvitie metodiki estestvoznaniya v dorevolyutsionnoy Rossii [Development of natural science methodology in prerevolutionary Russia]. Moskow: Uchpedgiz, 1958. 434 p. [in Russian]

11. Shulga I. Narysy z istorii' shkil'nogo pryrodoznavstva v Rosii. [Essays on the history of school science in Russia]. Kyiv : Rad. School, 1955. 290 p. [in Ukrainian] 
Prystupa Y. V. Historiography of school natural education in Ukraine at the the end of XX-beginning of XXI century

The renewal of the paradigm of natural education in all its stages is conditioned by the necessity of its correlation with the modern level of development of the natural sciences, the requirements for the modern educated person, the realities of the modern world and culture are an objective requirement of time. It is important that natural education contributes to the creation of a holistic view of the scientific picture of the world, human awareness of their place in the world, as an integral part of nature, social adaptation of young people to life in the transient conditions of socio-economic development of the country. Therefore, the problem of the development of school science education in Ukraine becomes urgent, but despite the considerable number of developments, explorations, studies that directly or indirectly affect it, there is not enough research to cover the historiography of the development of school science education in Ukraine at the end of XX-beginning XXI century. The article deals with the problem of development of school science education in Ukraine at the end of XX-beginning of XXI century. through the prism of historiographical discourse, which is important in analyzing the development of historical and pedagogical science as a coherent system of knowledge in the ratio of different directions of a single subject field of the history of pedagogy. On the basis of the analyzed sources three stages of formation of natural education are distinguished: the Soviet, the stage of restructuring of education and the modern stage. Each period has its own peculiarities in the coverage of problems caused by specific historical, ideological, socio-cultural, political factors, as well as the development of education and historical and pedagogical thought in Ukraine. Contemporary historians of the school of natural education are still facing a lot of problems, which await their solution, and require serious and in-depth development.

The growth of the value potential of school biological education in the 21st century necessitates the selection and structuring of the scientific provisions of biological science in accordance with the axiological principle.

Key words: historiography, changes, stages, pedagogical science, natural education, science, development, chronological sequence.

УДК 373.5.017:330.16

DOI https://doi.org/10.31392/NPU-nc.series5.2020.72-2.30

Прищена С. М.

\section{ФОРМУВАННЯ ПІДПРИЕМЛИВОСТІ ЯК ФІЛОСОФСЬКО-ПЕДАГОГІЧНОЇ СКЛАДОВОЇ ДУХОВНОЇ СФЕРИ ОСОБИСТОСТІ В УЧНІВ ОСНОВНОї ШКОЛИ}

Визначено актуальність означеної проблеми відповідно до сучасної ситуації та важливості законодавчо-нормативних документів. Розкрито та проаналізовано якості (відповідальність, самостійність, ініціативність, працьовиmість, творчість, наполегливість, організованість. чесність), щуо входять до поняття «підприємливість» як однієі з ключових компетентностей.

Визначено сутність поняття «підприємливість» з педагогічного, психологічного та філософського поглядів.

Підкреслено важливість формування підприємливості не лише на уроках з економіки, фінансової грамотності, інтелектуальної власності, але й на інших предметах закладу загальної середньої освіти.

Стисло розкрито суть, особливості та інструментарій кожного з етапів формування підприємницької компетентності. У статті нами виділено основних чотири етапи, описано на кожному з них завдання та дї всіх суб 'єктів освітнього процесу. Варто зазначити, щуо кожен із даних етапів є продовженням попереднього та початком наступного, адже всі етапи є системою у формуванні даної компетентності.

Аналізуючи кожен з етапів, нами визначено використання, переважно, методів активного навчання та заміна монологічного викладу на діалогічні форми навчання (мозковий штурм, системний аналіз, імітаційні тренінги та вправи, тематичні дискусії), які б створювали можливості школярам шукати розв'язки різних проблем, бути самостійними у прийнятті рішень та уміти висловити власну точку зору.

У статті нами проаналізовано мету та основні завдання українсько-польського проєкту «Шкільна академія підприємництва». Даний проєкт розкриває особливості формування підприємниџької компетентності як в урочний, так i в позаурочний час, пропонуючи форми роботи за межами школи, наприклад, виставки, клуби та інше.

Акцентовано увагу на тому, щзо реалізація усіх зазначених етапів зможуть допомогти сформувати креативність, уяву, мислення школярів.

Ключові слова: підприємливість, підприємницька компетентність, учні, методи навчання, заклад загальної середньої освіти, якості підприємливості, проєкт, підприємницька діяльність, проблемна ситуація, компетентнісний nidxid.

В Україні сучасна парадигма освіти ставить у центр освітньої діяльності формування компетентної особистості, результатом якої є готовність та здатність людини реалізувати свої знання і досвід у проблемних ситуаціях. На думку експертів Ради Свропи, компетентності передбачають спроможність особистості сприймати та відповідати на індивідуальні і соціальні потреби; формують комплекс ставлень, цінностей, знань та навичок.

Як зазначається в Законі України «Про освіту» (2017 р) «метою освіти є всебічний розвиток людини як особистості та найвищої цінності суспільства, іiі талантів, інтелектуальних, творчих і фізичних 